Article

\title{
The Relationship between Firm Size and Age, and Its Social Responsibility Actions-Focus on a Developing Country (Romania)
}

\author{
Alina Badulescu $\left.{ }^{1}{ }^{(}\right)$, Daniel Badulescu ${ }^{1, *}$, Tomina Saveanu ${ }^{2}$ and Roxana Hatos ${ }^{2}$ \\ 1 Department of Economics and Business, Faculty of Economic Sciences, University of Oradea, \\ 410087 Oradea, Romania; abadulescu@uoradea.ro \\ 2 Research Center for Competitiveness and Sustainable Development, Faculty of Economic Sciences, \\ University of Oradea, 410087 Oradea, Romania; tsaveanu@uoradea.ro (T.S.); rhatos@uoradea.ro (R.H.) \\ * Correspondence: dbadulescu@uoradea.ro; Tel.: +40-744-778-204
}

Received: 3 February 2018; Accepted: 11 March 2018; Published: 14 March 2018

\begin{abstract}
The concept of Corporate Social Responsibility covers a wide range of actions which have been practiced for many years in Western countries. As well as in other developing and transitional countries, the concept of social responsibility emerged in Romania after 1990, concurrently with the set-up of many non-governmental organizations (NGOs) and the entrance of multinational companies and was rapidly adopted by several firms. The main purpose of our paper is to investigate practices and actions related to social responsibility, which are undertaken by small and medium enterprises (SMEs) in Romania and to reveal which factors really matter in determining different degrees of involvement in Corporate Social Responsibility (CSR) actions. The level of social responsibility actions undertaken by SMEs often depends on the decisions of their managers and the value orientation of the entrepreneur. Moreover, the younger a firm is, the less likely it is that it gets involved in CSR. This is our main assumption: young ventures display a weaker propensity for CSR actions. In order to validate this hypothesis, we used survey data, collected from 84 SMEs, operating in Oradea, Romania. Data were collected between July-September 2016 and analysed by the authors through correlations, independent sample $T$-tests and linear regression modelling. Our findings reveal that there are significant differences between newly established ventures and those with a longer history; however, age is not a determining factor of CSR. Although, in the literature, there is no clear consensus regarding whether there is a different model of implementation of CSR related practices in developing and transitional countries, especially in the case of SMEs, our results show there are no essential differences between the models of CSR involvement as these are known in the theory and practice of developed countries.
\end{abstract}

Keywords: CSR; SMEs; entrepreneurship; firm's age; firm's size; developing countries; Oradea; Romania

\section{Introduction}

The last decades have witnessed dramatic changes in the relationships between the private sector, public authority and civil society. Companies have been challenged, not only by the major processes that occurred at the end of the twentieth century, such as globalisation, deregulation and privatisation, but also by society's expectations regarding firms' contributions to public welfare and social involvement. Although companies' interest in social involvement has existed since the beginning of capitalist organisation, its comprehension was rather in philanthropic terms, in a paternalistic and responsive framework. However, nowadays, the theory and practice of companies' social involvement consists of models, rights, obligations and behaviours of the companies within the society. 
These facts, together with the increasing dynamics of contemporary societies, have led to a new approach regarding Corporate Social Responsibility (CSR). Through CSR, companies have admitted that their role and impact on the economy and society can no longer reside only in seeking profit and gaining market shares, and they have a responsibility in social and environmental issues [1,2]. Moreover, the inclusion of these concerns in business strategies could be crucial in ensuring the long-term success of these companies. According to Rochlin and Christoffer [3], CSR has gained importance due to globalisation and increased competition, amplified size and influence of multinational corporations, restriction and redefining of the state's role in the economy and society, an increase in the activism of civil society at national and global level, and the growing importance of creative activities.

Gradually, large companies have started to implement CSR processes, such as public commitments to comply with standards, community investments, conforming and fostering stakeholder involvement, and systematic public reporting on social and environmental performance. CSR has grown beyond, both theoretically and practically, the area of philanthropy, money donations and charity actions. CSR has become an active way to include the interests of stakeholders, a way to keep the competitive advantage and to reconcile profit objective with long-term strategies. The natural consequence was that CSR has become an object of study, public debates and political actions, but also a matter of governance in most of the world's economies, in regional and global organisations. According to Zadek, Pruzan and Evans [4] the shaping of CSR started from redefining values-wealth creation must go along with the production of social and environmental goods and services-and continued with strategies, stating that firms consider social and environmental responsibility in strategic development plans. CSR was finally confirmed and adjusted as an effect of the public pressure, whereby consumers, public and private institutions, media and community representatives have pressed companies to assume also these social and community responsibilities-mainly environmental issues, labour standards and human rights [5].

\subsection{Social Responsibility: From Large Companies to SMEs}

Certainly, the term CSR directly refers to the activity of large, multinational corporations, but there are opinions considering that the term could be extended to other businesses, regardless of size, origin or objectives of the involved stakeholders. This shift and broadening of CSR's meanings started just from concerns regarding the environment, quality of social relationships, business performance and increasing influence of stakeholders over the behaviour of small businesses. Conversely, there was also a conscious approach of SMEs' managers to comply with the standards imposed by the responsible business governance, to voluntary incorporate the principles of CSR into daily business [6-9].

Intuitively, SMEs are reluctant to act involved in social responsibility (SR) actions, due to their small size and lack of significant human and financial resources (compared to multi-national enterprises-MNEs). Add to this the instability of the business environment which causes SMEs to excessively focus on their survival and short-term actions to the detriment of long-run plans, the lack of know-how (or know-who) to integrate SR into daily business, the lack of confidence in obtaining immediate and tangible results and the difficulty in measuring the intangible benefits [10].

On the other hand, unlike large companies, SMEs do not seek formal social responsible behaviour; they are better positioned in the social environment than MNEs and, thus, could achieve results with less effort and a more "natural" way than large companies. SMEs have fewer employees and therefore the spread of this kind of culture is easier; they are more flexible and can identify and respond more quickly to new ideas from the society. In fact, many of SMEs' actions are already socially or environmentally responsible [11]. Therefore, beyond the re-definition, in formal terms, of what they currently do, CSR could maximize the impact of existing practices in business and the awareness of the benefits of social actions among employees and customers, even if the positive effects might take a while to manifest. There are also opportunities and challenges for responsible entrepreneurial activity of SMEs. CSR could become a key competitive advantage through providing profitable and long-term 
contracts with large multinational companies. From the point of view of large companies, the reasons to outsource much of the production and/or operational processes require that selected suppliers and subcontractors equally observe responsible behaviour and identify and mitigate negative social and environmental impacts. In addition to these opinions regarding the compatibility between SMEs and social responsibility, the literature has identified a third opinion which focuses on finding common points and areas of interference to maximize the impact of socially responsible actions in society, regardless of their source. One of these could be public-private interaction, particularly in public procurement that could become more socially responsible. Another area of interference could be the support offered to SMEs in solving some obvious disadvantages (e.g., limited resources, knowledge and experience), in organizing and supporting policies and systematic SR actions. These disadvantages can be overcome, at least partially, by cooperation with Multinational Enterprises (MNEs). More specifically, in their social responsible actions and policies, MNEs may engage in the capacity building of their suppliers-i.e., the SMEs - helping to integrate social responsibility into their operations [10]. Finally, another possibility for shaping an integrated system of SR, to avoid wasting it with antagonistic groups (private vs. public, SMEs vs. MNEs), is to find and promote various resources, tools and best practices at all levels (i.e., regional, global or sectoral), to provide useful knowledge and practical advice concerning SR for SMEs.

\subsection{Are There Differences in the Practices Regarding the Implementation of CSR in Developed versus Developing Countries?}

Although there is relatively little literature on this topic, it is difficult to draw a unanimous conclusion. Viser [12] sees CSR in developing countries as a challenge inspired by the Millennium Development Goals- “a world with less poverty, hunger and disease, greater survival prospects for mothers and their infants, better educated children, equal opportunities for women, and a healthier environment" [13] (p. 3). In developing and transitional economies, formal CSR is usually practiced by large, national and multinational companies [14], while in the area of SMEs, CSR tends to be less formalized or institutionalized, focusing on specific aspects of developing countries, such as fair trade, supply chain and health. In these countries, CSR is most commonly associated with philanthropy or charity, as well as providing various community services as an effective way for business to create jobs, revenues and technology transfer.

However, there are studies revealing the formal and often hidden aspect of compliance to the principles of CSR. Jamali et al. [15] analysed how firms from developing countries can obtain funds and public support by focusing on CSR aspects of great visibility, while the situation of workers remains fundamentally unchanged. Zhang et al. [16] noticed a refrain of managers of small enterprises from China to engage in CSR, wondering whether CSR is a universal concept with a desired means of implementation across the developed and developing world [16] (p. 7647). Indeed, according to Visser, CSR issues in developing countries "present themselves as dilemmas or trade-offs, for example, development versus environment, job creation versus higher labour standards, strategic philanthropy versus political governance" [12] (p. 493).

According to Lindgreen et al. [17], the spread and type of CSR practices in developing and transitional countries do not differ significantly from the models of the developed countries, and they do not concentrate extensively on philanthropy and charity. The authors found some differences depending on the model of organisation of the business. "The stakeholder [ ... ] organisations are more likely to have a CSR department or employees who have time dedicated to dealing with these issues" [17] (p. 436), while the managers' belonging to a traditional capitalistic model are more reserved due, most probably, to a lack of specific benefits for the profit of the business itself.

\subsection{Social Responsibility: From New to Old Companies}

It is widely recognised that CSR involvement increases as firms become older, given that CSR leads to improvements in a firm's image on the market, increasing sales, profitability and the financial 
performance of the firm. Withisuphakorn and Jiraporn [18] provided a critical analysis of this opinion, relying on two hypotheses. First, the "outcome hypothesis" claims that the increased economic performance and the predictability of cash flow allow mature firms to invest more in CSR; on the other hand, younger firms, with less predictable cash flows, that are focused on survival or accelerated growth, lack the funds to invest in CSR activities. The opposing hypothesis, i.e., the "substitution hypothesis", claims that mature firms, regardless of performance and stable cash flows, have a reputation that does not need to be substituted by earning social goodwill through CSR campaigns and are, subsequently, less involved in CSR. On the other hand, young firms need to build their reputation, possibly through CSR involvement, and consequently get greater marginal benefits from CSR investments. Withisuphakorn and Jiraporn [18] support the "outcome hypothesis", i.e., firms, as they mature, invest more in CSR and become more responsible and involved in environmental protection. The "ageing" of the firms as an acknowledgement of their social responsibility was also stated by Robbins et al. [19]. They perceive CSR involvement as consisting of four stages, depending on the firm's age, with respect to the importance attributed to different stakeholders. At first, involvement starts with responsibility toward shareholders (1), then expands to employees (2) followed by an increased importance of the stakeholders from the firm's business environment (3); in the final stage (4), the firm acknowledges its responsibility to society as a whole [19]. However, the phases of the incorporation of CSR and sustainability principles may not be a linear, continuous and sequential process, but a process in which autonomous choice depends on "external and internal drivers and by their relative importance during the course of the company's CSR history" [20] (p. 682).

There are several empirical research studies and cases that have approached the issue of CSR involvement during a firm's life cycle. According to the Observatory of European SMEs, "there is a positive and statistically significant relationship between involvement in external social activities and age of the enterprise, in the sense that the percentage of SMEs involved in these activities increases with the number of years in business operations ... more than 5 years in business seems to be a 'point of change' in this respect" [21] (p. 25). Santos, investigating a consistent sample of Portuguese SMEs, stated that" the involvement of SMEs in the external community is directly related with the size of the company and its operational age" [22] (p. 496). In a study on the influence of Corporate Social (and Environmental) Responsibility (CS(E)R) on the competitiveness of SMEs in two developing countries (South Africa and Vietnam), Jeppesen et al. [23] found a relationship between age (but also size) and involvement of the company in CS(E)R, i.e., a company older than 10 years is likely to be one that has reached a medium size, has significant domestic and international openness, works with large firms and is clearly involved in CS(E)R activities. Finally, it should not be overlooked that an increase in age and size involves a higher level of formality in these CSR actions.

Trencansky and Tsaparlidis [24] found that a company's age is significantly and positively associated with certain CSR activities (such as the length of implementation periods of certified management systems and voluntary and philanthropic activities), but it is statistically insignificant regarding sustainability issues. This lead them to conclude that, although present among CSR determinants, the company's age "has a minor positive effect on the level of CSR activities" [24] (p. 51). On the other hand, Wiklund [25] concluded that the age of a company has virtually no influence on the type and level of involvement in CSR actions. Blomback and Wigren [26] proposed that only large, experienced companies with considerable material and human resources are able to integrate and effectively practice CSR activities. Yao, Wang and Song [27], aiming at identifying the determinants of corporate social responsibility disclosure (CSRD) in China, found that firm age (together with size, environmental and consumer sensitivity, media exposure, ownership concentration) is an important determinant of CSRD. However, contradicting the results of many previous studies, firm age was negatively correlated with the level of CSRD, an explanation residing in the specific nature of China's capital market. More precisely, younger Chinese companies are "more willing to disclose social information because they are more eager to attract bank loans and public investors than the older and more established firms" [27] (p. 9). 
CSR can also be described by the different levels of a company's involvement, understood both as an evolution to higher levels of complexity and commitment, but also in chronological terms-i.e., the moment of entry and the level of commitment in CSR is related to the company's age. Zadek [28] referred to time of commitment to CSR as a learning process; he starts with an initial stage which he names "defensive", as a response to external demands and challenges, followed by the compliance stage, in which society adopts (imitates) the behaviour of experienced economic and social actors, thus proving compliance with the regulations and passing signals of reliability to interested parties. The third stage, i.e., the managerial phase, leads the company to internalize previously formally assimilated CSR practices that now become routine, consolidating authority and managerial decisions. By default, it is followed by the strategic stage in which CSR practices become an integral part of the company's long-run strategy, an element of market differentiation and ensuring long-term growth. Finally, in the last stage, i.e., the civic stage, the company acts outside its own organisation and assumes the role of the speaker of the industry, the sector and even the community it is part of, the leader of collective actions at a national, regional or global level [28]. However, for most SMEs, the implementation of social responsibility practices remains very close to the first phases described above, where there is a set of CSR management activities that may contribute towards business success [ ... ] "without actually knowing it" [22] (p. 499). CSR as an integral part of sustainable, long-term strategies assimilated to the company's management philosophy and strategy, proactive, civic approaches to serious social issues (e.g., poverty, social exclusion, environmental degradation) remains very incipient in SME activity [22] (p. 499). Similar to the phases described by Zadek, but in a much more critical perspective, Visser described the "evolution of business responsibility in terms of five overlapping periods-the ages of greed, philanthropy, marketing, management and responsibility [ ... ] each of which typically manifests a different stage of CSR, namely, defensive, charitable, promotional, strategic and transformative (systemic) CSR" [29] (p. 7). Companies go through these ages and stages in a non-uniform way, but it is important to make the transition to systemic CSR in the dawning "Age of Responsibility", to overcome the first four periods (i.e., greed, philanthropy, marketing, and management) related to the environmental, social and ethical crises that we face. Otherwise, CSR simply will continue to fail [29] (p. 7).

The aim of this paper was to explore the impacts of firm size and age on the propensity for social responsibility actions undertaken by small and medium enterprises in a developing country. Our main finding was that neither age, nor size, influences the number and type of social actions undertaken. There are two relevant issues explaining social responsibility actions: the level of formalisation of CSR within the firms and the age of respondents. Our study fills a gap in the literature regarding the social responsibility of SMEs in developing countries. Moreover, our conclusions bring valuable information about the factors supporting the involvement in social responsibility actions.

In the first part of this paper we explore the scientific literature, starting with an introduction in the institutional setting of CSR, and ending with discussions regarding the determinants of social responsibility of SMEs. The second, methodological section describes the research method and sample and continues with the analysis of the relations between our considered variables. The third part provides an assessment of the impact of each considered independent variable on the social responsibility action scale, aiming at isolating the effect of the age of the firm. In the concluding section, we discuss the main findings and argue for some of the theoretical assumptions on the forms of CSR in developing countries.

\section{Theoretical Overview of Corporate Social Responsibility of SMEs}

Defining CSR is not an easy task as the approaches are various and sometimes controversial [30]. Moreover, excessive use of the acronym CSR instead of the complete and actual term "corporate social responsibility" is not only exaggerated, but it also indicates that the meaning and its intrinsic value are neglected or distorted [31,32]. According to Castka et al. [33] there are also overlaps and confusions with similar terms and definitions used in related fields, such as corporate sustainability, 
corporate social performance [34], or corporate social responsiveness [35], corporate citizenship [36], triple bottom line or social responsible behaviour. As Dahlsrud [37] underlined, "the challenge for business is not so much to define CSR, as it is to understand how CSR is socially constructed in a specific context and how to take this into account when business strategies are developed" [37] (p. 6).

The most frequent approaches to the topic of CSR refer to the efforts of the organisations to find an equilibrium between economic, environmental, social and legal requirements, to be considerate to the stakeholders, and to give something in return to the community [38], a way of being for the firm [39] (p. 19). Jones [40] approached CSR through the stakeholder theory: either a voluntary engagement of the management toward the thirds/stakeholders, or as a business behaviour considering that voluntary compliance to these principles and the involvement of employees, customers, suppliers, communities, brings additional benefits to the firm [30,41].

\subsection{Institutional Setting. How Legal and Institutional Systems Influence the Propensity of Firms for CSR?}

The theoretical approach to this issue started from the dichotomy between civil and common law systems, or more precisely, how common law countries privilege the interests of shareholders (financial performance, dividends, stock exchange rate etc.), while a civil law system promotes regulations that protect the interests of stakeholders [42-44]. According to Amor-Esteban et al. [45], even if companies worldwide adopt similar models of CSR practices, the involvement and profile of CSR activities "are strongly determined by the coercive institutional characteristics", and the most susceptible to act in a responsible manner are those operating in institutional environments with a judicial system which is both ample and oriented to the protection of stakeholders [44-46].

Demirbag et al. [47] nuance this stance of a close relationship between institutional setting and corporate social responsibility. Moreover, they state that, in the context of nations where the civil law ideal is most pronounced, such as those belonging to the French legal sub-family (like Romania, among others), voluntary CSR spending "is less than in more mixed or diluted civil law traditions, such as Scandinavian or German law" [47] (p. 1072). However, firms acting in civil law frameworks are more involved in formal CSR, compared to firms acting in shareholder dominant rights settings (i.e., common law systems). The only exception is charity, where firms in common law countries are noticeably more involved.

Finally, Demirbag et al. [47] did not find any specificity of CSR in formerly socialist countries or countries with a statist history. They explained it by the large diversity of this group of countries and their various development options during the last two decades. A stronger connection between CSR and the legal systems becomes more obvious in the involvement in explicit CSR actions (e.g., standards, reporting etc.), and, not least, in the commitment to fight against corruption: "socially responsible behaviour was more likely in settings where there is a stronger control on corruption [ ... ]. In other words, if firms are accustomed to being able to buy their way out of problems with regulators, they may feel less need to have to placate the public at large" [47] (p. 1072).

Steurer [48] proposed that CSR started as a neoliberal approach intending to reduce government regulations, but, in time, its development generated a co-regulation, i.e., governments developed minimal mandatory standards and quality control procedures for most aspects of CSR. The balance between voluntary and regulated actions should be maintained, because it is stimulating for responsible and ambitious firms to be involved in (and report) social and environmental actions, with the most suggestive example being that of the European Union [48]. Berger-Walliser and Scott [49] were doubtful about the transformation of the voluntary aspect of CSR in legal regulations as a positive change, favourable to the stakeholders (by diminishing the importance of shareholders), stating, in regard to firms having sufficient freedom to target their CSR actions to the areas which will finally lead to an increase in their profits, "The 'harder' the law, the more difficult it becomes to discern the true motivation behind a company's CSR policy" [49] (p. 218). Finally, the exclusion of legal regulations of CSR actions might reduce the possibility of progress or the creation of an adequate balance between society, authorities and the firms' sector. Even in the cases in which CSR and regulations are separated, 
they are, in practice, close-knit, and the government already plays an active role, e.g., minimal legal standards regarding the environment, work standards and fair competition [50].

\subsection{Social Responsibility in SMEs and Its Determinants}

In terms of organisation and planning, CSR activities in SMEs are mainly treated as an ad hoc issue [6] and do not fundamentally define the "job description" of a certain person, being instead the responsibility of the manager/owner or an experienced staff member [8,30]. In most cases, CSR activities in SMEs are related to the local community that is regarded as the most important stakeholder [41,51], through community projects and environmental actions (e.g., volunteering, charitable donations, recycling initiatives) [6,8,41]. For SMEs, social responsibility means the company's involvement in solving problems and expectations of the local community-supporting local events, creating jobs, economic growth, training and spin-off effects $[6,52]$ best practices and models for younger generations and potential local entrepreneurs. Of course, there is the opinion that all these engagements are, in fact, typical SME objectives and results and should not be artificially included as CSR actions [30] (p. 91).

The second line of action relates to the internal environment of the firm. It refers to the organisational culture [53] but without the rhetorical appearance often encountered in the practice of large corporations [54]. This may include interpersonal relationships, close knowledge of employees' profiles and expectations, reduced bureaucracy and direct and unmediated communication [55]. The existence of complex written plans and strategies, resulting from detailed and extensive debates, is rather an exception among small firms. SMEs maintain a high degree of optimism and attachment of employees who are able to boost them with increasing sales, profitability and a competitive edge [30,56]. In other words, these organisations focus on finding a dynamic balance between the selection of the most suitable employees and "socialisation of these and existing employees into the 'right' values" [30] (p. 93), including the CSR ones.

According to Mousiolis et al. [57] (p. 582) strategic decisions in SMEs are taken depending on the factors that matter in their environment: personal feelings, company resources, friends and family. However, these factors are not as relevant for MNEs, which usually value global social issues. Moreover, SMEs relate their involvement in CSR activities to the imminence of a problem and the possibility of faster solving, while MNEs formalize them by CRS's inclusion in plans and budgets, carefully weighting their effects on overall corporate strategy.

A constant concern of CSR research is that of identifying factors (or determinants) that significantly influence firms' decisions to enter and pursue CSR activities. For example, Roberts [58] and Moore [59], following the stakeholder theory approach, proposed that a company's age, size and the type of industry in which they perform (as independent variables) significantly influence involvement and performance in CSR (as dependent variables).

The effect of firm characteristics on CSR involvement was also demonstrated for Romanian SMEs [60]. Using data regarding the amounts offered by SMEs as donations or sponsorships, the authors proved that the amount donated is explained, mainly, by a firm's size (measured by turnover and number of employees) and age. Jeppesen et al. [23] found that the differences in action can be observed not only between MNEs and SMEs but also within the SMEs (i.e., medium sized enterprises versus small and micro enterprises) - "these differences according to size are related to factors such as (a) market relations, (b) age, and (c) the industry" [23] (p. 143).

Preuss and Perschke [61], and Vázquez-Carrasco and López-Pérez [62] concluded that socially responsible behaviour differs in terms of the size of the firms. Subsequently, while the main drivers of CSR actions, in the case of large and consolidated firms, are external pressure, business rhetoric, investment rationale, in the case of young and small business, these are related to internal motivation, "more silent/sunken and often rooted in deeply engrained cultural and religious values" [63] (p. 373), [12]. As for the relationships with stakeholders (fundamentally, the main beneficiaries of CSR actions), it is extensive, systematic and formalised in the case of large firms, and personalised, 
showing different degrees of intensity in the case of SMEs, influencing the amplitude of outcomes. Panwar et al. [64] highlighted that, excepting seeking differentiation through community engagement, the approach of small firms with regard to CSR is mostly characterised by ad hoc decisions, minimally related to their competitive strategies, while the gains in terms of public image are mainly associated with community, rather than environmental involvement. In a recent study, Gangi et al. [65] stated that "the favourable influence of CSR on the firms' capability of survivorship is more pronounced in SMEs than in large firms". Although admitting that firm size is positively correlated with CSR involvement, they proposed that the SMEs which are actively and honestly involved in CSR activities benefit more in terms of reduction of financial distress risk than large companies.

Another perspective on the intensity of CSR actions is given by the relationship between the involvement in CSR activities and the age of the entrepreneur, manager or, in some cases, the person responsible for CSR within a firm. Research is scarce in this regard. As Sweeney [8] and Vo [30] stated, the CSR activities in SMEs are usually are the responsibility of the manager/owner or an experienced staff member. This would mean that the relationship between the intensity and effectiveness of CSR actions, and the age (experience) of the responsible person is a direct one. For some stakeholders, the experience and the seriousness of these people mean commitment to the work and to the company's values, social contacts, preservation of the social and cultural capital and equilibrium between age groups, enabling the implementation of personnel policies [66]. On the other hand, a study from 2007, conducted by the Australian Center for Corporate Social Responsibility (ACCSR) on a large number of Australian firms, showed that nearly $70 \%$ of CSR executives aged between 26 to 45 years old, have relatively higher hierarchical positions in their organisations $(42 \%$ were either senior managers or executives, and almost another $40 \%$ were managers) and intended to continue their career in this field [67] (p. 9). In other words, CSR is far from being a marginal area of management "reserved" to former managers before retirement, or a necessary internship for top managers.

The diverse and often contradictory research outcomes caused some researchers to propose that there is an inconsistency (a limit) of CSR as long as the related aspects are not clearly defined [68] —for example, what is the social practice of companies and what are the standards (measurement scale) of a company's performance in terms of environment, social involvement, employees' rights [69] or [70]? Furthermore, Sturdivant and Ginter [71], Boutin-Dufrense and Savaria [72], Jenkins [6,73] and Ramos et al. [74] believe that research should consider, to a greater extent, the differences between sectors, industries, sizes and their impacts on CSR activities, in order to achieve useful and meaningful results.

\section{Research Method}

Starting from the theoretical basis, this study aimed at analysing the forms and the factors influencing social responsibility actions undertaken by SMEs in Bihor County, Romania. More specific topics such as types, forms and domains of social responsibility (SR) actions, expenditures for SR actions, the inclusion of SR aspects in strategic documents, existence of a employees for social responsibility matters, sources of decisions regarding SR actions, motivations for SR actions and the scale of social responsibility were explored in the questionnaire.

In this paper, we focus on investigating and comparing young and older SMEs regarding issues such as the maturity of social responsibility orientations, the type and domains of social responsibility actions, the attitudes of SME managers toward the role of the business sector in providing social welfare.

Based on the above-mentioned studies, supporting a significant positive correlation between the firm's age, size and welfare commitment on one hand, and CSR availability on the other hand [18,21-23], in specific legal systems $[47,49,50])$ and socioeconomic contexts [15-17], we put forward the following research hypotheses:

H1. The older a firm, the higher the propensity for social responsibility actions is. 
H2. The larger a firm, the higher the propensity for social responsibility actions is.

H3. The higher the level of formalisation of CSR related aspects, the higher the propensity for social responsibility actions is.

H4. The more a manager considers that providing welfare is the firm's role, the higher the propensity of his/her business for social responsibility actions is.

These issues were addressed based on the results of a pilot survey conducted among 84 SMEs from Oradea, Bihor County, Romania. The data was collected through an online and paper-based survey, during July-September 2016, the questionnaire (see Appendix A) being used in several data collection waves between 2014 and 2016. The questionnaire consisted of 23 questions, mostly with closed answers. The questions regarding types of actions had six items, and there were three questions on the level of formalisation as described in the data analysis presentation below [75]. Table 1 presents the main questions addressed in this paper.

Table 1. Description of variables used in the analyses.

\begin{tabular}{|c|c|c|c|}
\hline No. & Name & Description & Measures \\
\hline 1 & $\begin{array}{l}\text { The social } \\
\text { responsibility } \\
\text { action scale }\end{array}$ & $\begin{array}{l}\text { Summative scale regarding the type of social actions undertaken by } \\
\text { organisations based on question (Q)11_1: "Did your company organise } \\
\text { the following activities: donations and sponsorship, involvement in } \\
\text { community development projects, employee voluntary programs, } \\
\text { social marketing campaigns, supporting a social cause, training for } \\
\text { other people then its own employees, complementary programs for } \\
\text { employees". The answers were yes/no to each. }\end{array}$ & $\begin{array}{l}\text { Mean: } 1.73 \\
\text { Median: } 1 \\
\text { Std. Deviation: } 1.759 \\
\text { Skewness: } 1.020 \\
\text { Kurtosis: } 118 \\
\text { Minimum: } 0 \\
\text { Maximum: } 6\end{array}$ \\
\hline 2 & Year of founding & $\begin{array}{l}\text { "Year of establishment" (Q6) } \\
\text { Indicates the year when the business started. } \\
\text { This variable was also recoded in order to group firms: old-founded } \\
\text { between } 1991 \text { and 2009, and new-founded between } 2010 \text { and 2012, } \\
\text { based on the OECD and World Bank categorisations between new and } \\
\text { old firms }\end{array}$ & $\begin{array}{l}\text { Mean: } 2004.17 \\
\text { Median: } 2007 \\
\text { Std. Deviation: } 6.982 \\
\text { Skewness: }-0.774 \\
\text { Kurtosis: }-0.992 \\
\text { Minimum: } 1991 \\
\text { Maximum: } 2012\end{array}$ \\
\hline 3 & $\begin{array}{l}\text { Number of } \\
\text { employees }\end{array}$ & Indicates the number of employees at the time of response (Q3). & $\begin{array}{l}\text { Mean: } 61.21 \\
\text { Median: } 9.00 \\
\text { Std. Deviation: } 226.93 \\
\text { Skewness: } 4.65 \\
\text { Kurtosis: } 20.63 \\
\text { Minimum: } 1 \\
\text { Maximum: } 249\end{array}$ \\
\hline 4 & $\begin{array}{c}\text { Turnover } \\
\text { (thousands of } \\
\text { Euros) }\end{array}$ & Indicates the firm's turnover in the previous year (2015) (Q4). & $\begin{array}{l}\text { Mean: } 2084.56 \\
\text { Median: } 196.37 \\
\text { Std. Deviation: } 8579.54 \\
\text { Skewness: } 4.671 \\
\text { Kurtosis: } 20.74 \\
\text { Minimum: } 34.87 \\
\text { Maximum: } 42,313.90\end{array}$ \\
\hline 5 & $\begin{array}{l}\text { Level of } \\
\text { formalisation }\end{array}$ & $\begin{array}{l}\text { Mean scale based on the questions: "Are there social responsibility } \\
\text { components in the profile of your firm's activity?" (Q7); "Is there } \\
\text { explicit reference regarding social responsibility values or principles in } \\
\text { your firm's strategic or operational documents?" (Q8) and "Is there a } \\
\text { department or a person employed for dealing with CSR?" (Q9). } \\
\text { The answers were yes/no to each. }\end{array}$ & $\begin{array}{c}\text { Mean: } 0.5000 \\
\text { Median: } 0.0000 \\
\text { Std. Deviation: } 0.82514 \\
\text { Skewness: } 1.660 \\
\text { Kurtosis: } 2.066 \\
\text { Minimum: } 0.00 \\
\text { Maximum: } 3.00\end{array}$ \\
\hline 6 & $\begin{array}{l}\text { Managers' } \\
\text { opinions regarding } \\
\text { their responsibility } \\
\text { towards collective } \\
\text { welfare }\end{array}$ & $\begin{array}{l}\text { Self-assessment on a 10-point scale for the question, "To what extent do } \\
\text { you consider that social welfare is the responsibility of the business } \\
\text { sector?"(Q6), where } 1 \text { means that social welfare is solely the } \\
\text { responsibility of governments and } 10 \text { that the welfare of the society } \\
\text { should be a priority for the business sector. }\end{array}$ & $\begin{array}{c}\text { Mean: } 4.73 \\
\text { Median: } 5.00 \\
\text { Std. Deviation: } 2.050 \\
\text { Skewness: }-0.035 \\
\text { Kurtosis: }-0.322 \\
\text { Minimum: } 1 \\
\text { Maximum: } 9\end{array}$ \\
\hline 7 & Age of respondent & $\begin{array}{l}\text { Indicates the age of the respondent (in years) (your age, in the final } \\
\text { section, "Finally, we have some general questions"). }\end{array}$ & $\begin{array}{c}\text { Mean: } 42.85 \\
\text { Median: } 40.00 \\
\text { Std. Deviation: } 9.698 \\
\text { Skewness: } 0.322 \\
\text { Kurtosis: }-0.766 \\
\text { Minimum: } 27 \\
\text { Maximum: } 60\end{array}$ \\
\hline
\end{tabular}


All firms in the sample were small and medium in size. The average number of employees was 24 , with a standard deviation of 50.03, a minimum of one employee and a maximum of 249 . The turnover registered an average of 2,084,558 Euros, a median value of 196,375 Euros and a standard deviation of $8,579,540.9$ Euros, indicating a rather large variation in firm size in the sample.

Regarding the age of the firms, there is also wide variety, with the oldest being founded in 1991 and the newest in 2012. In order to compare the issues related to social responsibility, we grouped the firms in two groups: older firms, which started their activity between 1991 and 2009 and newer firms, which started their activities after 2010 (the five year of activity distinction for new firms is based on World Bank [76,77] and OECD distinctions [78]). Most of the SMEs in the sample fell under the older group consisting of firms established between 1991 and 2009 (70\%), while 30\% were established between 2010 and 2012.

\section{Results and Discussion}

\subsection{Level of Formalisation}

The questionnaire started with some general issues regarding the strategic approach of CSR-related aspects, and then focused on the specific actions organized by the firms. We will comparatively present all these aspects, starting with the level of formal embedment of CSR-related aspects in the activity of the surveyed firms. The responses are presented in Figure 1 as responses to dichotomic questions. In $4.2 \%$ of the cases, there is a department or a person employed for dealing with CSR. In the $16.7 \%$ of cases, there are explicit references regarding social responsibility values or principles in strategic or operational documents of the SMEs, while over $29 \%$ of the respondents consider that there are social responsibility components in the profile of the SME's activity. The responses suggest the lack of maturity regarding social responsibility of SMEs, which is in line with other research results reported in the field. Moreover, none of the young firms surveyed have formalized the CSR-related aspects. These findings do not necessarily mean that SMEs have a disinterest in social responsibility issues and that young SMEs are not at all involved in any social responsibility actions, but it is merely the indication of the level at which SMEs formalise such an approach.

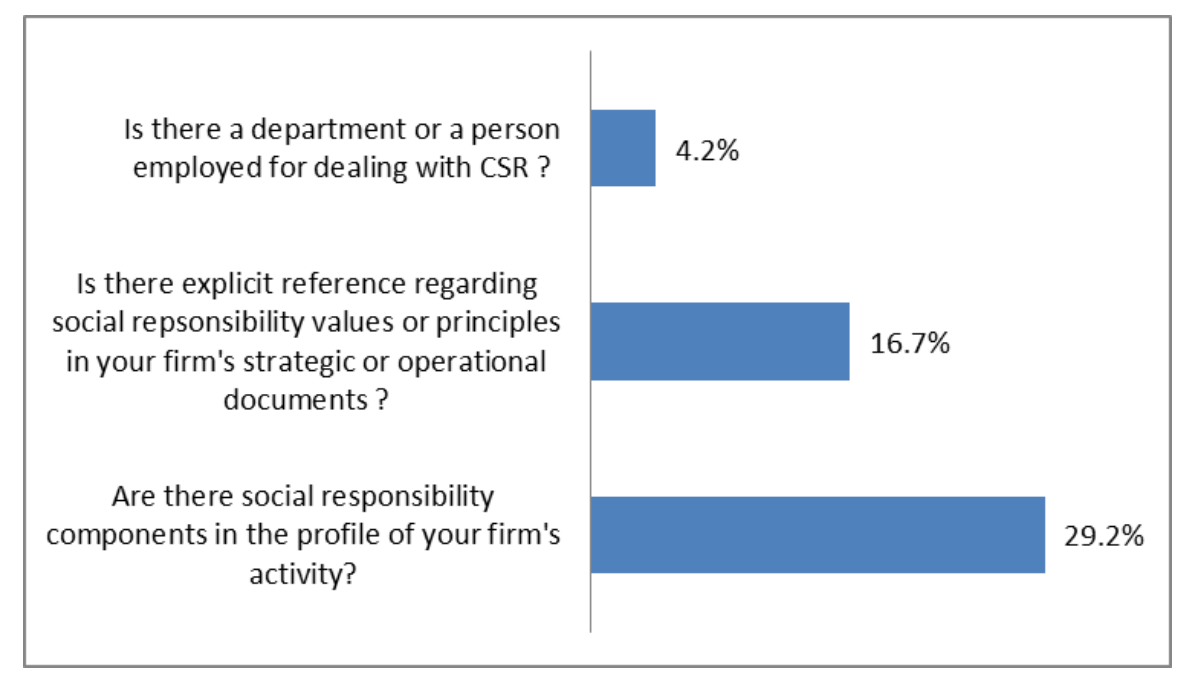

Figure 1. Level of formalisation of Corporate Social Responsibility (CSR) in the surveyed SMEs (percentages).

The scale of the responses that measures the level of formalisation reflected by the mean $($ mean $=0.50 ; \mathrm{SD}=0.825)$ suggests that the firms' levels of formalisation are low (see Figure 2). 


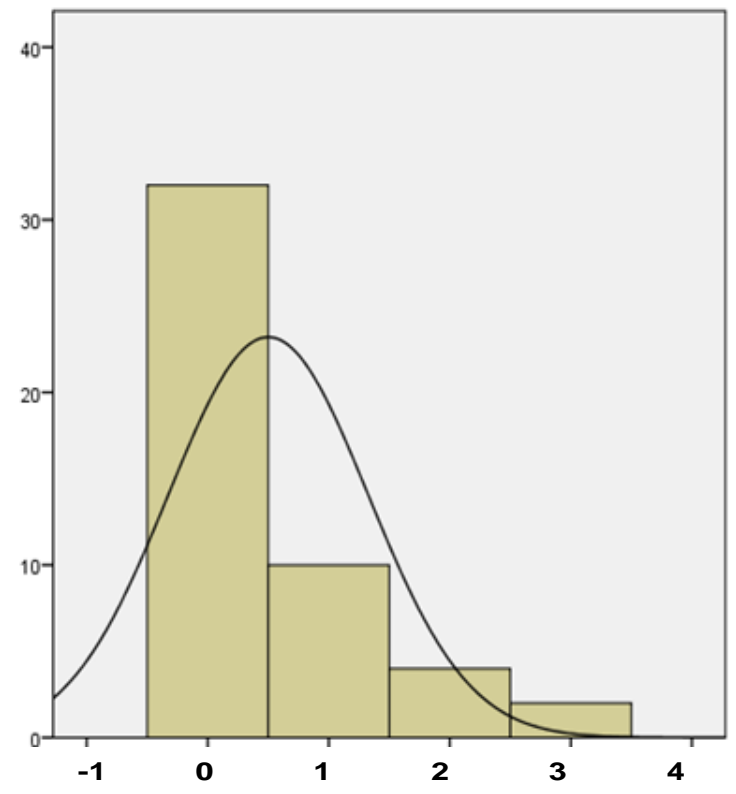

Figure 2. The distribution of the level of formalisation scale.

\subsection{Types of Social Responsibility Actions}

When questioning whether companies have organized specific CSR actions, the image is much more diverse. Respondents were asked to choose, from a list with seven types of actions, which are the actions they have organised in the last year. The most frequent types of activities for both young and older firms (see Figure 3) are donations or sponsorships, followed by complementary programs for employees. There was one type of activity not undertaken by any of the firms in the sample (social marketing campaigns) and consequently, it was eliminated from the figure.

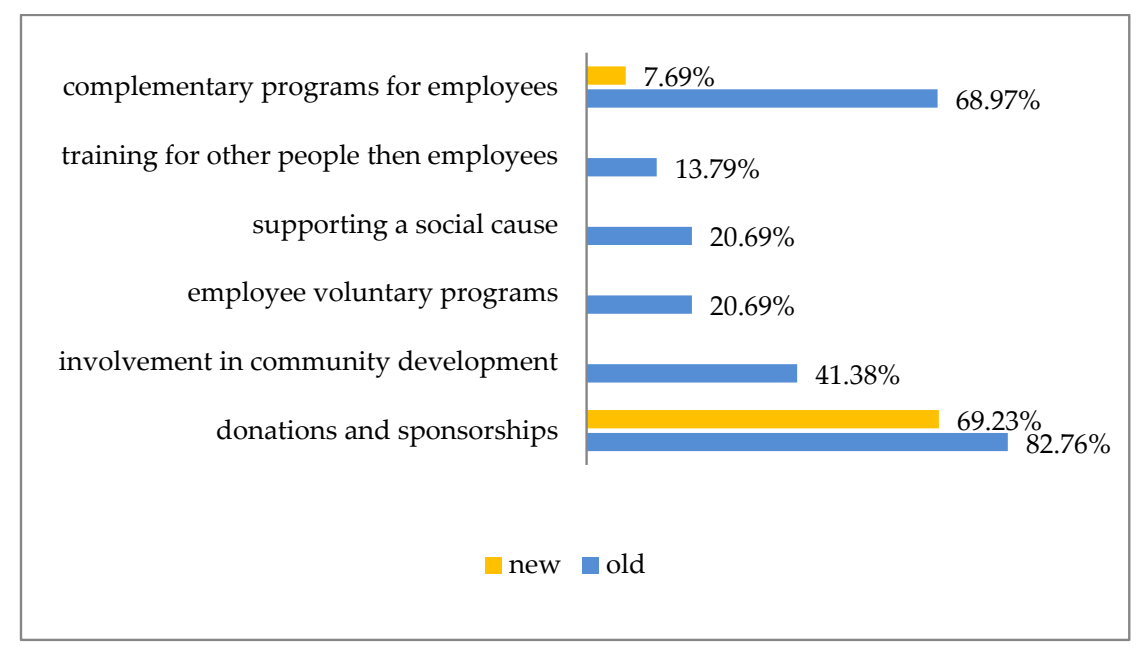

Figure 3. Type of social responsibility actions undertaken by the surveyed companies (percentages).

Based on these registered responses, we computed a social responsibility action summative scale (see Figure 4). There are companies with no activities (actually, most of them), while there are also very involved companies, which organize up to six specific types of social responsibility actions. We must note that it is possible that some companies are strongly involved in only one type of activity and, consequently, they will score low on this scale; nonetheless we consider that the propensity for social responsibility actions is a good indicator of their involvement. 


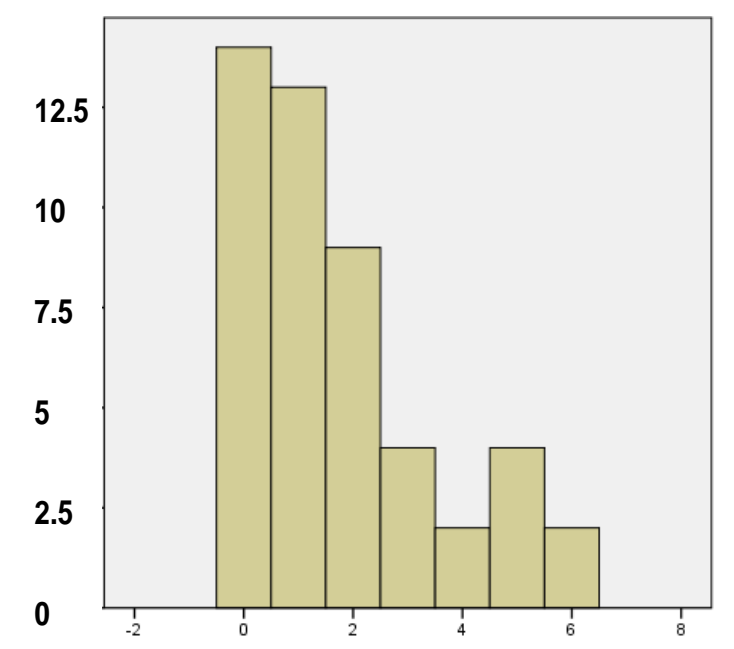

Figure 4. The distribution of the social responsibility action scale.

When investigating the differences between old and new companies, we found a significant difference regarding the number of types of social responsibility actions undertaken. Old firms in the sample undertake significantly more types of actions (mean $=2.18 ; \mathrm{SD}=1.9)$ than new firms (mean = $0.71 ; \mathrm{SD}=0.6 ; \mathrm{t}(43)=3.9, p=0.00)$. This finding supports the assumption that the age of the firm is related to the social responsibility activities. The results of the independent sample $T$-tests show that older firms had undertaken more types of social actions in the last year.

The hypothesis that there are different determinants of CSR was verified by analysing the relationship between the two variables, i.e., level of formalisation and the existence of at least one social action in a firm. We consider that if there is explicit reference regarding social responsibility or principles in a firm's official documents, or even if there are social responsibility components in the profile of an SME's activity, then they are more likely to get involved in community activities. Using independent sample $T$-tests, our analyses showed that there is a significant difference between the means of the level of formalisation and the undertaking of at least one social responsibility action $(\mathrm{t}(33)=-4.54, p=0.00)$. This is to say that firms which undertake at least one social action have a higher level of formalisation (mean $=0.70 ; \mathrm{SD}=0.90$ ) than firms that have no social actions (mean $=0.00$; $\mathrm{SD}=0.00$ ). Based on this result, we cannot state which the determining factor is-whether being more formalised in the direction of CSR has the effect of organizing more social activities, or whether having more activities causes a firm to formalise these activities. However, formalising CSR shows a constant commitment and investment in this direction, and consequently, we consider it to be a predictor for future social involvement.

In order to analyse the magnitude of CSR actions, we also asked our respondents about the amounts spent for different types of activities. The results, as presented in Table 2, indicate that the largest amounts are directed to donations and sponsorships. The expenses directed to other types of activities are rather small—up to 20,150 Euros for the previous year (2015).

Table 2. Expenses of firms for different types of social responsibility actions.

\begin{tabular}{lcccc}
\hline & Less than 215 & Between 215 and & Between 2150 and \\
Euros & $12.5 \%$ & $50.0 \%$ & $0.0 \%$ & Over 10,730 Euros \\
\hline Donations and sponsorship & $0.0 \%$ & $16.7 \%$ & $4.2 \%$ & $8.3 \%$ \\
Involvement in community development projects & $4.2 \%$ & $8.3 \%$ & $0.0 \%$ & $0.0 \%$ \\
Employee voluntary programs & $0.0 \%$ & $0.0 \%$ & $0.0 \%$ & $0.0 \%$ \\
Social marketing campaign & $8.3 \%$ & $4.2 \%$ & $0.0 \%$ & $0.0 \%$ \\
Supporting a social cause & $0.0 \%$ & $4.2 \%$ & $0.0 \%$ & $0.0 \%$ \\
Training for other people then its own employees & $12.5 \%$ & $22.9 \%$ & $8.3 \%$ & $0.0 \%$ \\
Complementary programs for employees & & & 10,730 & \\
\hline
\end{tabular}


We investigated whether there are differences between old and new SMEs concerning the amount of money invested in CSR actions by using independent sample T-tests. However, based on our data, there are no differences in this regard between new and old firms.

\subsection{Attitudes of Managers Regarding the Role of Businesses to Promote Social Welfare}

Moreover, we investigated the attitudes of managers regarding the role of firms in providing welfare. Even considering the relative distance between attitude and behaviour, we consider that managers who acknowledge their role in the development of the communities are more likely to get involved. This assumption is confirmed by the relationship between these two variables (i.e., attitudes of managers and the propensity for social responsibility type of actions). The relationship between the two variables (i.e., the attitude of managers and the scale of social responsibility actions) was tested through correlation, as both variables are continuous. There was a strong correlation between the attitude of managers regarding the role of firms in providing collective welfare and their social responsibility actions (Pearson correlation $=0.587 ; p=0.00$ ).

Respondents were asked to place their response on a 10-point scale, from 1 (corresponding to "collective welfare should be solely the responsibility of governments") to 10 (corresponding to "collective welfare should be a priority for the business sector"). The responses are presented in Figure 5, displaying a rather normal distribution, with a remarkable peak at the average response.

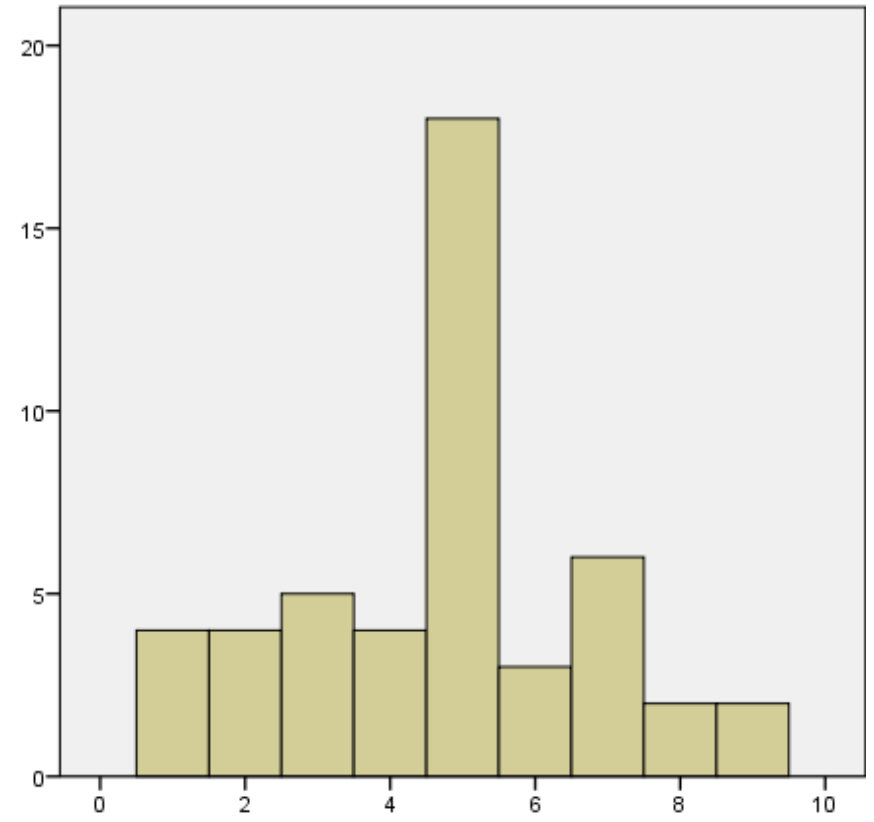

Figure 5. The distribution of responses on the role of business sector in providing social welfare.

We also investigated the differences between the responses of managers of young versus older SMEs in this regard. Managers of older firms (mean $=5.15$; SD $=2.1$ ) consider that business sector should play an active role in providing collective welfare to a significantly higher degree than younger firms managers do (mean $=3.17 ; \mathrm{SD}=1.5, \mathrm{t}(45)=2.271, p=0.028$ ).

These results suggest that the age of the firm affects the social responsibility actions: the older a firm, the more likely it will undertake some form of social involvement. Moreover, managers of older companies are more aware of the role of the business sector in providing collective welfare, making these SMEs even more prone to getting involved in social responsibility actions. There was no significant difference regarding the age of respondents between old and new firms. The attitude of managers regarding a firm's role in providing social welfare was not correlated with the age 
of the respondents, and also the age of respondents was not correlated with the scale of social responsibility actions.

\subsection{Impact of Different Factors on the Social Responsibility Type of Actions Scale}

Nevertheless, we have tried to isolate the effect of the age of the firm in explaining social responsibility. In order to do this, we constructed a linear regression model for the dependent variable, social responsibility action scale. The independent variables included the age of the SME (the year when founded), the age of the manager/owner, the size (number of employees and turnover), the level of formalisation and the attitude of managers regarding the role of the companies in providing collective welfare. The model described in Table 3 has an $R$ square 0.63 , as the model explains $63 \%$ of the variation of the dependent variable. Tolerance was greater than $0.10(0.620)$ and the variance inflation factor was less than 10 (1.613), indicating that multicollinearity was not an issue. The values are presented in Table 3 . The endogeneity issues could not be further investigated given the data and the available instruments.

Table 3. Linear regression model explaining the social responsibility actions scale.

\begin{tabular}{|c|c|c|c|c|c|c|c|}
\hline & \multicolumn{2}{|c|}{$\begin{array}{l}\text { Unstandardized } \\
\text { Coefficients }\end{array}$} & \multirow{2}{*}{$\frac{\begin{array}{l}\text { Standardized } \\
\text { Coefficients }\end{array}}{\text { Beta }}$} & \multirow[t]{2}{*}{$\mathbf{t}$} & \multirow[t]{2}{*}{ Sig. } & \multicolumn{2}{|c|}{ Collinearity Statistics } \\
\hline & B & Std. Error & & & & Tolerance & VIF \\
\hline (Constant) & 57.459 & 55.031 & & 1.044 & 0.303 & & \\
\hline Year of founding & -0.028 & 0.027 & -0.109 & -1.016 & 0.316 & 0.705 & 1.419 \\
\hline Turnover (thousands of euro) & 0.000 & 0.000 & -0.124 & -1.266 & 0.213 & 0.845 & 1.184 \\
\hline Level of formalization & 1.430 & 0.231 & 0.669 & 6.181 & 0.000 & 0.687 & 1.457 \\
\hline $\begin{array}{l}\text { Managers' opinions regarding their } \\
\text { responsibility towards collective welfare }\end{array}$ & 0.155 & 0.096 & 0.181 & 1.618 & 0.113 & 0.643 & 1.556 \\
\hline Age of respondent & -0.042 & 0.021 & -0.233 & -2.041 & 0.048 & 0.620 & 1.613 \\
\hline
\end{tabular}

As presented in Table 3, there were only two significant variables explaining the social activity scale: the level of formalisation, and the age of the manager. As expected, a higher level of formalisation of CSR at the level of the firm was association with a larger number of social responsibility actions. Consequently, our third hypothesis was supported.

The negative sign regarding the age of the respondent shows that the younger the respondent, the higher the score of social activities. It indicates that young managers are more open towards CSR activities, possibly as an effect of education in a developing country.

Hypotheses 1, 2 and 4 can be refuted based on our results. The model proves that there is no direct effect of the age of firms on the number of social responsibility actions. Further, size, measured as turnover for the previous year, did not influence the number of social responsibility actions. This result is in line with several previous research studies, such as Wiklund [56], Blomback and Wigren [57], Jeppesen et al. [52] and Santos [49], who were less willing to associate CSR actions with young and small firms. The managers' attitudes regarding the role of businesses in providing social welfare proved also to be unrelated to social responsibility actions, though we expected that in SMEs the manager will have the determining role in shaping a socially responsible organisational culture.

\section{Conclusions and Limitations}

In our study, the influence of a firm's age on social responsibility of SMEs proved not to be linear. There are different levels of formalisation of social responsibility processes between older and newer firms. While older firms tended to have some reference to social responsibility in their strategic documents and to hold departments or people specifically for this purpose, young firms lacked this formalisation altogether. Regarding the domains of involvement, while young firms were less involved in social responsibility actions, they showed a higher interest in community development programs. Considering the forms of involvement, there was continuity between older and newer firms, as they all preferred to offer donations and sponsorships. Nevertheless, new firms were significantly less involved in 
social responsibility actions (measured as a cumulative scale), confirming our hypothesis that young firms are less involved in social responsibility actions. However, there was no significant impact of an SME's age on social responsibility actions, when analysed along with other factors such as firm size and the managers' attitudes regarding collective welfare. Testing these relationships on larger samples of SMEs would give the bases for refuting or supporting our hypothesis. The sample size is the main limitation of our research, followed by the fact that the SME representatives surveyed during our research are most probably more open to the subject of CSR. We would expect that, in the total population of SMEs in Bihor County, Romania, the involvement in social responsibility actions would be less prominent. Further research is intended to investigate the relationship between the economic development of regions and the social responsibility profiles and action of companies. Given the diversity of economic development in Romania, constructing comparative samples at regional level would bring significant insight into the analysis of the impact of economic context on social responsibility. A larger sample would also increase the generality and impact of our conclusions. Although the results of our research only partially confirm our initial expectations, they also suggest that CSR should not be considered an "institution", whose standards are difficult to meet by the average SME. Policy makers should exploit the inner positive predisposition of managers for social and community actions and promote those policies that revalue CSR as a source of business opportunities for SMEs, for their internal and external stakeholders, for investors, etc. The impact of the manager's age, along with the importance of an explicit formalisation of CSR-related aspects indicates that educating social responsibility should be a goal for business training. Younger people who have been trained more recently are more likely to promote CSR, which can be a starting point for future developments in the field. Promoting best practices through formal education as well as with practitioners' commitment could increase the involvement of SMEs in social responsibility, both as practical action and on a strategic level, by embedding CSR in a firm's developmental policies.

Acknowledgments: No grants were used for the research and publication of this article.

Author Contributions: The paper is a result of a collaborative work. A.B. and D.B. did the literature review, T.S. and R.H. did quantitative data collection, analysis and discussion, D.B., T.S. and R.H. prepared the first draft, A.B. worked at the abstract, language and final revisions.

Conflicts of Interest: The authors declare no conflict of interest.

\section{Appendix A}

\section{Questionnaire \\ Realities and Views on CSR in Romania}

This questionnaire was designed to analyse social engagement practices as well as managers' views on this issue. The questionnaire is addressed to managers of companies from Bihor County. CSR refers to the fulfilment of a wide range of duties of an economic, moral, and legal nature towards the society. Your answers to this questionnaire will only be used for scientific purposes, while respecting the anonymity of all answers. Thank you for your time!

1. Name of the company

2. Field

3. Number of employees

4. Turnover

5. Year of establishment

6. To what extent do you think that collective welfare is a responsibility of business environment?

Please choose on the scale below, where

\begin{tabular}{|c|c|c|c|c|c|c|c|c|c|}
\hline 1 & 2 & 3 & 4 & 5 & 6 & 7 & 8 & 9 & 10 \\
\hline $\begin{array}{l}\text { Social } \\
\text { of gov }\end{array}$ & ats. & e re & pility & \multicolumn{6}{|c|}{ Social welfare should be a priority for businesses. } \\
\hline
\end{tabular}


7. In the company you work in, are there any CSR components within the activities?

$$
\text { 1. yes } 0 . \text { no }
$$

8. Do strategic or operational documents in the company you work in explicitly mention values or principles of social responsibility?

$$
\text { 1. yes } 0 . \text { no }
$$

9. Is there a department or a person employed in your company to handle social responsibility issues?

$$
\text { 1. yes } 0 . \text { no }
$$

10. In the last five years, in which of the following areas did the company you work in carry out social responsibility activities?

\begin{tabular}{llcc}
\hline \multicolumn{1}{c}{ Area } & Yes & No \\
\hline A & Sports & 1 & 0 \\
B & Culture & 1 & 0 \\
C & Environmental protection & 1 & 0 \\
D & Education & 1 & 0 \\
E & Community development & 1 & 0 \\
F & Charity & 1 & 0 \\
G & Charity (religious) & 1 & 0 \\
H & Others, please specify & 1 & 0 \\
\hline
\end{tabular}

11. Which of the following actions have been taken in your company within the last year? How about the past five years?

\begin{tabular}{llcccc}
\hline & \multicolumn{1}{c}{ Nature of the Action } & 1. In the Past 12 Months & \multicolumn{2}{c}{ 2. In the Past 5 Years } \\
\hline & & Yes & No & Yes & No \\
\hline A & Donations and sponsorship & 1 & 0 & 1 & 0 \\
B & Involvement in community development projects & 1 & 0 & 1 & 0 \\
C & Employee voluntary programs & 1 & 0 & 1 & 0 \\
D & Social marketing campaign & 1 & 0 & 1 & 0 \\
E & Supporting a social cause & 1 & 0 & 1 & 0 \\
F & Training for other people then its own employees & 1 & 0 & 1 & 0 \\
G & Complementary programs for employees & 1 & 0 & 1 & 0 \\
& others, please specify... & 1 & 0 & 1 & 0 \\
\hline
\end{tabular}

12. What are the approximate amounts invested by your organisation over the past 12 month in these actions (tick the appropriate box according to the answers above):

\begin{tabular}{llccc}
\hline \multicolumn{1}{c}{ Nature of the action } & $\begin{array}{c}\text { 1. Less than } \\
\text { 215 Euros }\end{array}$ & $\begin{array}{c}\text { 2. Between 215 } \\
\text { and 2150 Euros }\end{array}$ & $\begin{array}{c}\text { Between 2150 and } \\
\text { 10,730 Euros }\end{array}$ & $\begin{array}{c}\text { Over 10,730 } \\
\text { Euros }\end{array}$ \\
\hline A & Donations and sponsorship & 1 & 2 & 3 \\
B & Involvement in community development projects & 1 & 2 & 3 \\
C & Employee voluntary programs & 1 & 2 & 3 \\
D & Social marketing campaign & 1 & 2 & 3 \\
E & Supporting a social cause & 1 & 2 & 3 \\
F & Training for other people then its own employees & 1 & 2 & 3 \\
G & Complementary programs for employees & 1 & 2 & 4 \\
& Others, please specify... & 1 & 2 & 4 \\
\hline
\end{tabular}

13. What do you think are the direct benefits to your organisation from this type of action? Please circle the version that best fits your opinion.

\begin{tabular}{lcccc}
\hline & To a Very Small Extent & To a Small Extent & To a Large Extent & To a Very Large Extent \\
\hline Solving problems of the community & 1 & 2 & 3 & 4 \\
Employee loyalty & 1 & 2 & 3 & 4 \\
A positive image of the company & 1 & 2 & 3 & 3 \\
Client loyalty & 1 & 2 & 3 & 4 \\
Financial gain & 1 & 2 & 3 & 4 \\
Others, please specify ... & 1 & 2 & 4 \\
\hline
\end{tabular}


14. Your company has partnerships that deal with social responsibility actions with the following types of organisations:

\begin{tabular}{clcc}
\hline & \multicolumn{1}{c}{ Partner } & Yes & No \\
\hline A & NGO & 1 & 0 \\
B & Public administration institutions & 1 & 0 \\
C & Educational or research institutions & 1 & 0 \\
D & Others, please specify ... & 1 & 0 \\
\hline
\end{tabular}

15. Does the company you work in have a web page?
1. yes
0 . no

15. A. If yes, are the CSR actions presented on this web page?
1. yes
0. no

16. Which of the following cases best describes the way social responsibility actions are chosen in your company? Please choose only one situation, the one that best suits your situation!

a. We rely on social or environmental diagnoses made by experts,

b. We choose from the requests received from the beneficiaries,

c. The company manager chooses the domains we are involved in.

17. Do you agree with the following statements regarding social responsibility activities in the case of the company you work in?

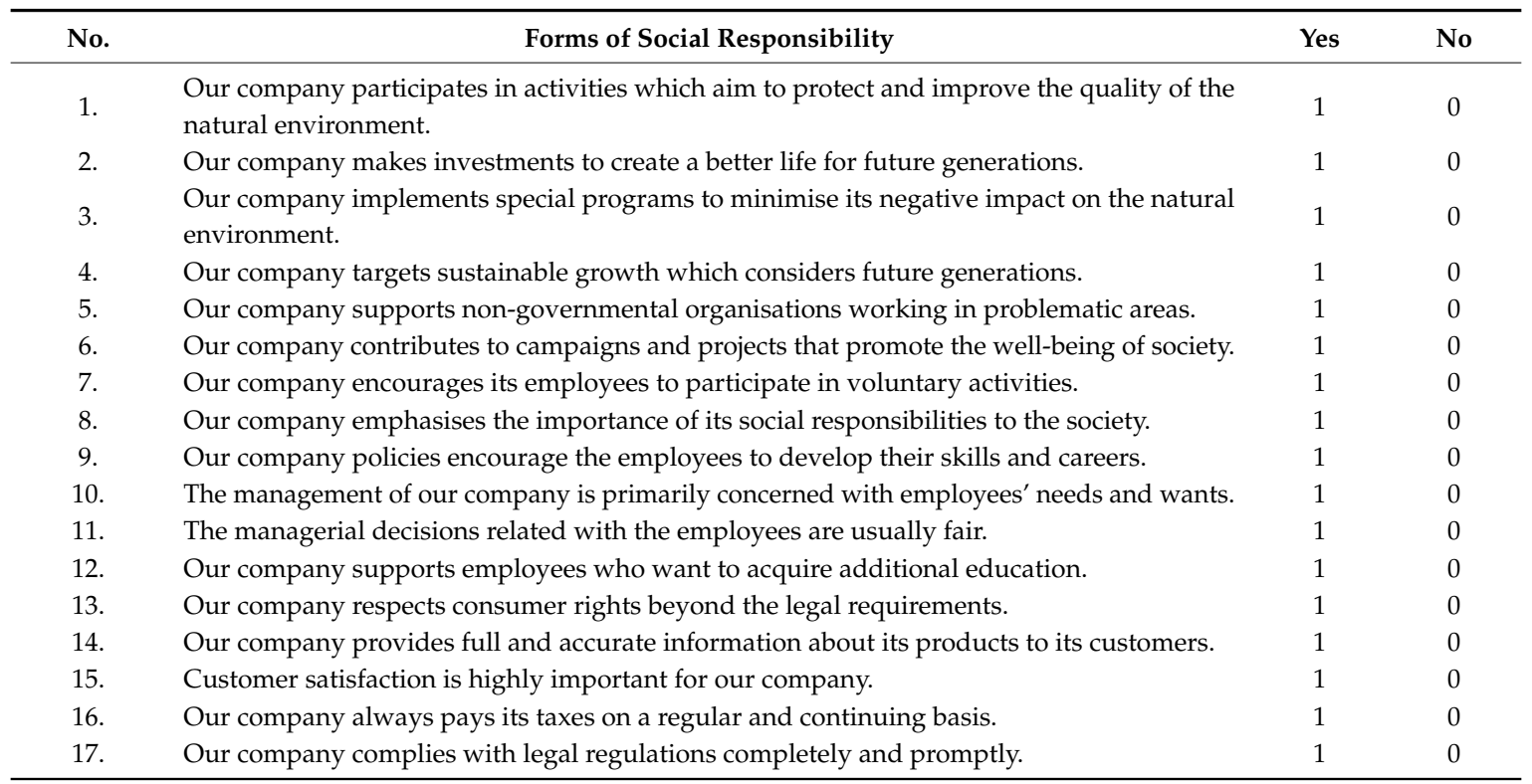

Finally, we have some general questions:

What position do you occupy?

Your seniority:

Your age:

Your gender: a. Female b. Male.

Thank you for your time and your openness!

\section{References}

1. Szegedi, K.; Fülöp, G.; Bereczk, Á. Relationships between Social Entrepreneurship, CSR and Social Innovation: In Theory and Practice. Int. J. Soc. Behav. Educ. Econ. Bus. Ind. Eng. 2016, 10, 1421-1426.

2. Tont, D.M.; Tont, M.D. An overview of innovation sources in SMEs. Oradea J. Bus. Econ. 2016, 1, 58-67. 
3. Rochlin, S.; Christoffer, B. Making the Business Case: Determining the Value of Corporate Community Involvement; Boston College Centre for Corporate Community Relations: Chestnut Hill, MA, USA, 2000.

4. Zadek, S.; Pruzan, P.; Evans, R. Building Corporate Accountability. Emerging Practices in Social and Ethical Accounting, Auditing and Reporting; Earthscan: London, UK, 1997; ISBN 978-1853834134.

5. Raynard, O.; Forstater, M. Corporate Social Responsibility: Implications for Small and Medium Enterprises in Developing Countries; United Nations Industrial Development Organization: Vienna, Austria, 2002.

6. Jenkins, H. Small Business Champions for Corporate Social Responsibility. J. Bus. Ethics 2006, 67, 241-256. [CrossRef]

7. Spence, L.J. CSR and small business in a European policy context: The five "C"s of CSR and small business research agenda. Bus. Soc. Rev. 2007, 112, 533-552. [CrossRef]

8. Sweeney, L. Corporate social responsibility in Ireland: Barriers and opportunities experienced by SMEs when undertaking CSR. Corp. Gov. Int. J. Bus. Soc. 2007, 7, 516-523. [CrossRef]

9. Olaru, M.; Stoleriu, G.; Şandru, I. Social Responsibility Concerns of SMEs in Romania, from the Perspective of the Requirements of the EFQM European Excellence Model. Amfiteatru Econ. J. 2011, 13, 56-71.

10. Aston, J.; Anca, C. Socially Responsible Small and Medium Enterprises (SMEs): Guide on Integrating Social Responsibility Into Core Business. Project Co-Funded by the European Social Fund: Association of Romanian Exporters and Importers (ANEIR). 2011. Available online: https://www.astoneco.com/sites/default/files/ public/downloads/downloads-smart/sme-guide-book-en.pdf (accessed on 3 January 2018).

11. Obrad, C.; Petcu, D.; Ghergheş, V.; Suciu, S. Corporate Social Responsibility in Romanian Companies-Between Perceptions and Reality. Amfiteatru Econ. J. 2011, 13, 43-55.

12. Visser, W. Corporate Social Responsibility in Developing Countries. In The Oxford Handbook of Corporate Social Responsibility; Crane, A., McWilliams, A., Matten, D., Moon, F., Siegel, D.S., Eds.; Oxford University Press: Oxford, UK, 2008; pp. 473-499. ISBN 978-0199211593.

13. United Nations. Millennium Development Goals Report 2006; United Nations Department of Economic and Social Affairs: New York, NY, USA, 2006.

14. Visser, W.; Matten, D.; Pohl, M.; Tolhurst, N. The A to Z of Corporate Social Responsibility; Wiley: London, UK, 2007. [CrossRef]

15. Jamali, D.; Lund-Thomsen, P.; Khara, N. CSR Institutionalized Myths in Developing Countries: An Imminent Threat of Selective Decoupling. Bus. Soc. 2017, 56, 454-486. [CrossRef]

16. Zhang, D.; Morse, S.; Kambhamptati, U.; Li, B. Evolving Corporate Social Responsibility in China. Sustainability 2014, 6, 7646-7665. [CrossRef]

17. Lindgreen, A.; Swaen, V.; Campbell, T.T. Corporate Social Responsibility Practices in Developing and Transitional Countries: Botswana and Malawi. J. Bus. Ethics 2009, 90, 429-440. [CrossRef]

18. Withisuphakorn, P.; Jiraporn, P. The effect of firm maturity on corporate social responsibility (CSR): Do older firms invest more in CSR? Appl. Econ. Lett. 2015, 23, 298-301. [CrossRef]

19. Robbins, S.; Bergman, R.; Stagg, I.; Coulter, M. Management, 2nd ed.; Prentice Hall: Sydney, Australia, 2000; ISBN 978-1-442-50023-5.

20. Pistoni, A.; Songini, L.; Perrone, O. The how and why of a firm's approach to CSR and sustainability: A case study of a large European company. J. Manag. Gov. 2016, 20, 655-685. [CrossRef]

21. European Commission. Observatory of the European SMEs No. 4. European SMEs and Social and Environmental Responsibility; Office for Official Publications of the European Communities: Luxembourg, 2002.

22. Santos, M. CSR in SMEs: Strategies, practices, motivations and obstacles. Soc. Responsib. J. 2011, 7, 490-508. [CrossRef]

23. Jeppesen, S.; Kothuis, B.; Ngoc Tran, A. FOCALES 16: Corporate Social Responsibility and Competitiveness for SMEs in Developing Countries: South Africa and Vietnam; Agence Française de Développement: Paris, France, 2012.

24. Trencansky, D.; Tsaparlidis, D. The Effects of Company's Age, Size and Type of Industry on the Level of CSR. The Development of a New Scale for Measurement of the Level of CSR. Master's Thesis, Umeå School of Business and Economics, Umeå, Sweden, 2014.

25. Wiklund, J. The Sustainability of the Entrepreneurial Orientation-Performance Relationship. Entrep. Theory Pract. 1999, 24, 37-48. [CrossRef]

26. Blombäck, A.; Wigren, C. Challenging the importance of size as determinant for CSR activities. Manag. Environ. Qual. Int. J. 2009, 20, 255-270. [CrossRef] 
27. Yao, S.; Wang, J.; Song, L. Determinants of Social Responsibility Disclosure by Chinese Firms; Discussion Paper 72; China Policy Institute, School of Contemporary Chinese Studies, University of Nottingham: Nottingham, UK, 2011.

28. Zadek, S. The Path to Corporate Responsibility (From the December 2004 Issue). Available online: https:/ / hbr.org/2004/12/the-path-to-corporate-responsibility (accessed on 12 December 2017).

29. Visser, W. CSR 2.0. Transforming Corporate Sustainability and Responsibility; Springer: Berlin/Heidelberg, Germany, 2014; ISBN 978-3-642-40874-8.

30. Vo, L.C. Corporate social responsibility and SMEs: A literature review and agenda for future research. Probl. Perspect. Manag. 2011, 9, 89-97.

31. Roberts, S. Supply chain specific? Understanding the patchy success of ethical sourcing initiatives. J. Bus. Ethics 2003, 44, 159-170. [CrossRef]

32. Fischer, J. Social responsibility and ethics: Clarifying the concepts. J. Bus. Ethics 2004, 52, 391-400. [CrossRef]

33. Castka, P.; Balzarova, M.A.; Bamber, C.J.; Sharp, J.M. How can SMEs effectively implement the CSR agenda? A UK case study perspective. Corp. Soc. Responsib. Environ Manag. 2004, 11, 140-149. [CrossRef]

34. Clarkson, M.B.E. A stakeholder framework for analyzing and evaluating corporate social performance. Acad. Manag. Rev. 1995, 20, 92-117. [CrossRef]

35. Arlow, P.; Gannon, M. Social responsiveness, corporate structure, and economic performance. Acad. Manag. Rev. 1982, 7, 235-241. [CrossRef]

36. Matten, D.; Crane, A. Corporate citizenship: Toward an extended theoretical conceptualization. Acad. Manag. Rev. 2005, 30, 166-179. [CrossRef]

37. Dahlsrud, A. How Corporate Social Responsibility is Defined: An Analysis of 37 Definitions. Corp. Soc. Responsib. Environ Manag. 2006, 15, 1-13. [CrossRef]

38. Gössling, T.; Vocht, C. Social role conceptions and CSR policy succes. J. Bus. Ethics 2007, 74, 363-372. [CrossRef]

39. Gazzola, P.; Mella, P. Corporate Performance and Corporate Social Responsibility (CSR). A necessary choice? Econ. Azziendale Online 2006, 3, 1-22.

40. Jones, M.T. The Traditional Corporation, Corporate Social Responsibility and the 'Outsourcing' Debate. J. Am. Acad. Bus. Camb. 2005, 6, 91-97. Available online: http:/ /hdl.handle.net/10536/DRO/DU:30032803 (accessed on 12 December 2017).

41. Longo, M.; Mura, M.; Bonoli, A. Corporate social responsibility and corporate performance: The case of Italian SMEs. Corp. Gov. Int. J. Bus. Soc. 2005, 5, 28-42. [CrossRef]

42. Matten, D.; Moon, J. "Implicit" and "Explicit" CSR: A Conceptual Framework for a Comparative Understanding of Corporate Social Responsibility. Acad. Manag. Rev. 2008, 33, 404-424. [CrossRef]

43. La Porta, R.; Lopez-De-Silanes, F.; Shleifer, A.; Vishny, R. Legal determinants of external finance. J. Financ. 1997, 52, 1131-1150. [CrossRef]

44. Kolk, A.; Perego, P. Determinants of the adoption of sustainability assurance statements: An international investigation. Bus. Strategy Environ. 2010, 19, 182-198. [CrossRef]

45. Amor-Esteban, V.; García-Sánchez, I.-M.; Galindo-Villardón, M. Analysing the Effect of Legal System on Corporate Social Responsibility (CSR) at the Country Level, from a Multivariate Perspective. Soc. Indic. Res. 2017. [CrossRef]

46. Campbell, J. Institutional analysis and the paradox of corporate social responsibility. Am. Behav. Sci. 2006, 49, 925-938. [CrossRef]

47. Demirbag, M.; Wood, G.; Makhmadshoev, D.; Rymkevich, O. Varieties of CSR: Institutions and Socially Responsible Behaviour. Int. Bus. Rev. 2017, 26, 1064-1074. [CrossRef]

48. Steurer, R. The role of governments in corporate social responsibility: Characterising public policies on CSR in Europe. Policy Sci. 2010, 43, 49-72. [CrossRef]

49. Berger-Walliser, G.; Scott, I. Redefining Corporate Social Responsibility in an Era of Globalization and Regulatory Hardening. Am. Bus. Law J. 2018, 55, 167-218. [CrossRef]

50. Cominetti, M.; Seele, P. Hard soft law or soft hard law? A content analysis of CSR guidelines typologized along hybrid legal status. uwf UmweltWirtschaftsForum 2016, 24, 127-140. [CrossRef]

51. Besser, T.L.; Miller, N. Is the good corporation dead? The community social responsibility of small business operators. J. Socio-Econ. 2001, 33, 221-241. [CrossRef] 
52. Wennekers, S.; Thurik, R. Linking entrepreneurship and economic growth. Small Bus. Econ. 1999, 13, 27-55. [CrossRef]

53. Mella, P.; Gazzola, P. Capitalistic Firms as Cognitive Intelligent and Explorative Agents. The Beer's VSM and Mella's Most Views. Manag. Dyn. Knowl. Econ. 2015, 3, 645-674.

54. Badulescu, D.; Petria, N. Social Responsibility of Romanian Companies: Contribution to a "Good Society" or Expected Business Strategy? Ann. Univ. Oradea. Econ. Sci. 2013, 22, 590-600.

55. Nielsen, A.; Thomsen, C. Investigating CSR communication in SMEs: A case study among Danish middle managers. Bus. Ethics 2009, 18, 83-93. [CrossRef]

56. Davies, I.A.; Crane, A. Corporate social responsibility in small-and medium-size enterprises: Investigating employee engagement in fair trade companies. Bus. Ethics 2010, 19, 126-139. [CrossRef]

57. Mousiolis, D.T.; Zaridis, A.D.; Karamanis, K.; Rontogianni, A. Corporate Social Responsibility in SMEs and MNEs. The Different Strategic Decision Making. Procedia Soc. Behv. 2015, 175, 579-583. [CrossRef]

58. Roberts, R.W. Determinants of Corporate Social Responsibility Disclosure: An Application of Stakeholder Theory. Account. Org. Soc. 1992, 17, 595-612. [CrossRef]

59. Moore, G. Corporate Social and Financial Performance: An Investigation in the U.K. Supermarket Industry. J. Bus. Ethics 2001, 34, 299-315. [CrossRef]

60. Saveanu, T.; Abrudan, M.-M. Trends in the Social Responsibility Expenditures of Small and Medium Enterprises from Oradea. Mediterr. J. Soc. Sci. 2015, 6, 212-217. [CrossRef]

61. Preuss, L.; Perschke, J. Slipstreaming the larger boats: Social responsibility in medium-sized firms. J. Bus. Ethics 2010, 92, 531-551. [CrossRef]

62. Vázquez-Carrasco, R.; Eugenia López-Pérez, M. Small \& medium-sized enterprises and Corporate Social Responsibility: A systematic review of the literature. Qual. Quant. 2013, 47, 3205-3218. [CrossRef]

63. Jamali, D.; Zanhour, M.; Keshishian, T. Peculiar Strengths and Relational Attributes of SMEs in the Context of CSR. J. Bus. Ethics 2009, 87, 355-377. [CrossRef]

64. Panwar, R.; Nybakk, E.; Hansen, E.; Pinkse, J. The effect of small firms' competitive strategies on their community and environmental engagement. J. Clean. Prod. 2016, 129, 578-585. [CrossRef]

65. Gangi, F.; Meles, A.; Monferrà, S.; Mustilli, M. Does Corporate Social Responsibility Help the Survivorship of SMEs and Large Firms? Glob. Financ. J. 2018, in press. Available online: https:/ / www.sciencedirect.com/ science/article/pii/S1044028317304106 (accessed on 2 February 2018).

66. Němec, O.; Surynek, A. Age management as a part of Corporate Social Responsibility. In Proceedings of the 9th International Days of Statistics and Economics, University of Economics, Prague, Czech Republic, 10-12 September 2015; pp. 1180-1190.

67. Australian Centre for Corporate Social Responsibility (ACCSR). The CSR Manager in Australia. Research Report on Working in Corporate Social Responsibility; Australian Centre for Corporate Social Responsibility: Melbourne, VIC, Australia, 2007.

68. Delai, I.; Takahashi, S. Sustainability measurement system: A reference model proposal. Soc. Responsib. J. 2011, 7, 438-471. [CrossRef]

69. Turker, D. Measuring Corporate Social Responsibility: A Scale Development Study. J. Bus. Ethics 2008, 85, 411-427. [CrossRef]

70. Portney, P.R. The (Not So) New Corporate Social Responsibility: An Empirical Perspective. Rev. Environ. Econ. Policy 2008, 2, 261-275. [CrossRef]

71. Sturdivant, F.D.; Ginter, J.L. Corporate social responsiveness: Management attitudes and economic performance. Calif. Manag. Rev 1997, 19, 30-39. [CrossRef]

72. Boutin-Dufresne, F.; Savaria, P. Corporate Social Responsibility and Financial Risk. J. Invest. 2004, 13, 57-66. [CrossRef]

73. Jenkins, H. A Critique of Conventional CSR Theory: An SME Perspective. J. Gen. Manag. 2004, 29 , 37-57. [CrossRef]

74. Ramos, T.; Cecilio, T.; Douglas, G.; Caeiro, S. Corporate sustainability reporting and the relations with evaluation and management frameworks: The Portuguese case. J. Clean. Prod. 2013, 52, 317-328. [CrossRef]

75. Badulescu, A.; Badulescu, D.; Saveanu, T.; Hatos, R. SMEs and social responsibility: Does firm age matter? In Proceedings of the STRATEGICA Conference "Opportunities \& Risks in the Contemporary Business Environment", Bucharest, Romania, 20-21 October 2016; pp. 963-975. 
76. Ayyagari, M.; Demirguc-Kunt, A.; Maksimovic, V. Small vs. Young Firms across the World: Contribution to Employment, Job Creation, and Growth. World Bank Policy Research Working Paper, No. 5631. 2011. Available online: https: / / ssrn.com/abstract=1807732 (accessed on 5 March 2018).

77. Aga, G.; Francis, D.C.; Meza, J.R. SMEs, Age, and Jobs. A Review of the Literature, Metrics, and Evidence. World Bank Policy Research Working Paper, No. 7493. 2015. Available online: https:/ / ssrn.com/abstract=2690632 (accessed on 5 March 2018).

78. Organisation for Economic Co-operation and Development (OECD). Young SMEs, Growth and Job Creation; OECD: Directorate for Science, Technology and Industry: Paris, France, 2014; Available online: https: / /www.oecd.org/sti/young-SME-growth-and-job-creation.pdf (accessed on 7 March 2018).

C 2018 by the authors. Licensee MDPI, Basel, Switzerland. This article is an open access article distributed under the terms and conditions of the Creative Commons Attribution (CC BY) license (http://creativecommons.org/licenses/by/4.0/). 